\title{
Improving Initial Teacher Education by Using the Project-Based Approach
}

\author{
Silvia Nikolaeva \\ PhD Sofia University St. Kliment Ohridski \\ Bulgaria
}

\begin{abstract}
:
This paper presents the results from a recently performed research on the effectiveness of different project-based strategies and practices for the learning and teaching implemented in both formal and non-formal educational environment. The research methodology integrates methods and tools for parallel study of both social and educational areas of the project-based teaching-learning interaction: surveys, comparative questionnaires, focus groups, case study and experimental teacher training. The collected data show that school projects are a welcoming and enjoyable experience for both students and teachers. They appreciate significant advantages of the approach, as compared to traditional methods and strategies. At the same time, they identify specific risks and challenges that can negatively affect their achievements, communication, satisfaction, or academic and social effectiveness. Probably, the most significant conclusion from the research is that the skills and competences for projectbased teaching and learning can be effectively developed by both formal teacher training programs and project-based practices (internships). On the basis of the performed experimental teacher training program (its results have been already implemented in the bachelor program for Pedagogy students at Sofia University), improvements were made to several project-based strategies and techniques. Specific conclusions and recommendations have been formulated regarding the possibilities to improve teacher competences and excellence through participation in school / learning projects $^{\text {ee }}$ development and management.
\end{abstract}

Key words: project-based learning and teaching; socio-educational effectiveness of projects; curriculum; student teachers.

Corresponding author: Silvia Nikolaeva

E-mail: nikolaevas@yahoo.com

Educational Research eJournal - ISSN 2254-0385

(C) Faculty of Education. University of Alicante

DOI: 10.5838/erej.2012.11.04 


\section{Introduction}

Project-based teaching and learning forms the basis of the so called project method or project approach in education. It means to perform authentic, active and diverse learning by doing, experimenting and/or creating, which has opened new prospects for practical application at every educational level and in every type of context. This explains why project-based thinking and action now have such a huge impact on the initial teacher education. Current teachers usually identify project work both as part of the academic curriculum they and also as a specific methodology for their initial vocational education. It is exactly the inter-connection between its different practical applications that makes the project-based approach so important in the search for appropriate tools to improve the synergy between theoretical and practical aspects of preservice teacher education. However, this method's effects and results may vary depending on the different starting points for analysis and/or design. My remarks will be supported further on by the findings of a recently held research, focused in measuring the effectiveness of Comenius 1 School projects on the basis of opinions and experiences of teachers and students, involved in their implementation. First of all, however, I would like to shortly assess the nature of the project and its applications in the field of education which will help to answer the leading question of this discussion.

Nowadays, the term "project" denominates the contents and meaning of a wide range of activities and events. The usage of the term can refer to a number of activities such as:

- Traditional architectural or engineering projects,

- Daily routine of "home projects".

- Art manifestations like new songs, art installations or performance projects.
- Finally, such powerful project activities as the management of global social projects.

Among all of this rich variety of applications of the project method, those related to education have emerged quite early in history. Despite the conventional myth that the project method was for the first time developed in the USA (Kilpatrick, 1918; Stimson, 1915) at the beginning of the $20^{\text {th }}$ century and notably in the area of vocational education, recent researches relate its first manifestations to the practice of the so called architectural contests organized by the oldest European architectural academies in Rome (1697) and Paris (1765). These initially annual events were meant to invite student architects to demonstrate their professional abilities and artistic talents by performing genuine architectural tasks such as designing important public buildings, spaces or temples. Since then, the authenticity of project-based education (teaching \& learning) serves as one of its strongest characteristics, turning it to a durable, everlasting paradigm in education [1].

The historical review reveals that the concept of teaching through projects reached the United States in 1865, where it served as an educational tool in manual training, agricultural education, and general science [1]. Later, in the 1920-1930"s, the project method was actively analyzed and popularized by its "classical outsider" William H. Kilpatrick [2]. He defined the final purpose of project-based learning as "character building".

Learning of all kinds and in its all desirable ramifications best proceeds in proportion as wholeheartedness of purpose is present. With the child naturally social and with a skilful teacher to stimulate and guide his purposing, we can especially expect that kind of learning we call character building. The necessary reconstruction consequent upon these considerations offers a most alluring 'project' to the teacher who but dares to purpose. [3]. 
M. Branom was among the first authors to recognize the special contribution of W. Kilpatrick to the conceptualisation of the learning project in education, considered as a ,wholehearted purposeful activity in a social situation. According to Branom:

The conception of Prof. Kilpatrick, in some respects, is a radical departure from the commonly held viewpoint. The emphasis is not placed upon concrete, objective achievement or upon a complex problem as such, but upon a unit of work, involving whole-hearted, purposeful activity. Small problems, as well as large, may be projects. There may be all degrees of activity from an activity carried on under dire compulsion to an activity that is absolutely whole-hearted and purposeful. [4].

Perhaps the most significant practical impact of such a re-assessment is the consistent spread of school/learning projects in all areas and levels of the educational systems and institutions. Only understanding project-based education as a sustainably developing complex of relatively independent applications can present in a realistic way its rich educative and developmental potential which contributes to both global and local educational goals and means for centuries. Not accidentally, authors have discussed the multi-dimensional functionality of projects even more than a century ago.

The word project represented somewhat varying concepts as long as it was part of the general rather than specific vocabulary of the educational field... With the inclusion of the word project in the terminology of pedagogy, the varying specific concepts, independently adopted by different leaders, have persisted. [4].

This reality provides a starting point for a more precise definition of some of the most popular and frequently used terms and meanings of "projects" in the area of education. According to Jane Henry [5], a variety of terms have been in use for referring to different types of projectbased learning. This author mentions especially the project exercise (miniprojects); the project component/s (one or more projects that form part of a larger course); the project courses (courses incl. substantial project element); the projectbased courses (all the assessment in the course is based upon series of miniprojects); the project credits (courses consisting entirely of one big project similar to thesis or dissertation); the project approach (project work as one of many types of methods or forms); the project method/orientation ("refers to situations where institutions teach entirely or largely through projects, offering students a discovery or problem-based approach to learning [4]). The most popular ones among them are the employment of the project method and the project approach constructs which integrate several of the existing other types of project-based learning and teaching (exercises, components, courses or credits).

The variety of project-based education practices also explains the rich diversity of learning projects. W. Kilpatrick [3] has devised four types of projects for his method: construction (such as writing a play), enjoyment (such as attending a concert), problem (for instance, discussing a complex social problem like poverty), and specific learning (learning of skills such as swimming). Nowadays, there are even much more detailed classifications of projects in education.

Despite the existing rich variety of project typologies and constructs in the area of education, certain confusion is observed in the use of the term and the related concepts. This has guided me to look for an appropriate way to systemize all these categories. Basic criteria for the systematisation are the different concepts, constructs and contexts of project-based planning and work in education (see Figure 1). The project concepts vary from teaching/learning as a project, social and/or organizational development as a 
Figure 1. Concepts, constructs and contexts of project-based planning and work in education

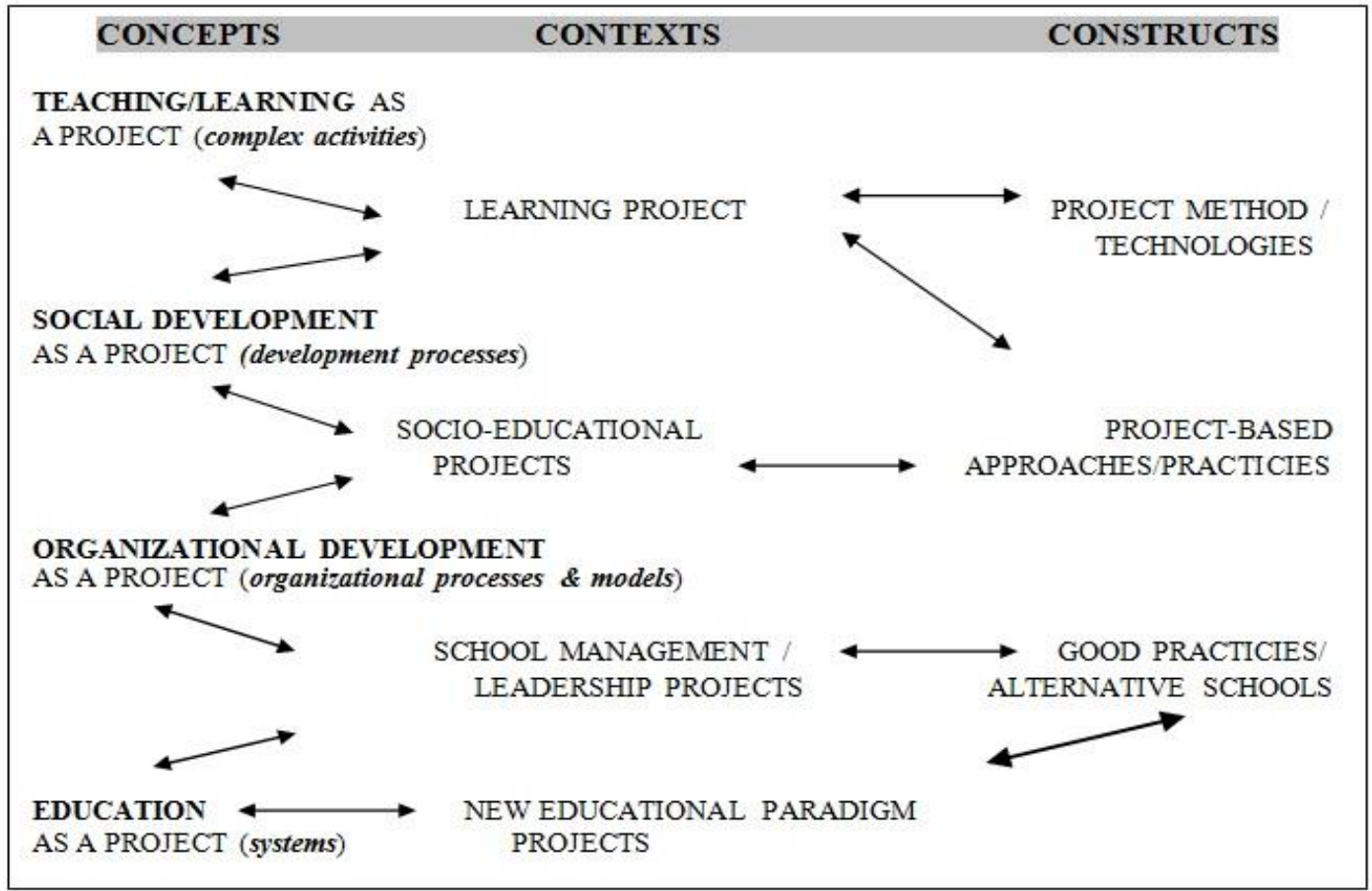

project, up to education as a complex project (integrating the rest of the concepts). These concepts are applied thanks to the implementation of several project constructs project method, approaches or models. The role of a specific filter between theoretical concepts and applied constructs is played by the corresponding educational context learning projects, socio-educational projects, experimental (pilot) projects for new educational models.

Using the mapped dimensions of educational project's concepts, contexts and constructs I would like to analyse their manifestations and usages in the initial teacher education from closer.

\section{Project-based learning and teaching as a part of the curriculum of initial teacher education}

When speaking about project-based learning and teaching as part of a specific curriculum for pre-service teacher education, at least two important objectives are being envisaged:
- Teaching/learning through learning projects.

- Achieving social development through school/socio-educational projects.

Usually, school projects are used by inservice teachers not only to reach academic standards, but also to enhance students' social, citizenship and development education. According to the findings from the recently conducted Bulgarian research, the implementation of Comenius I projects in the country has targeted a balanced socioeducational effectiveness (see figures $2 \& 3$ ).

Figure 2. Socio-educational effectiveness of Comenius projects' goal According to collected data Comenius projects target a balanced socio-educational effectiveness.

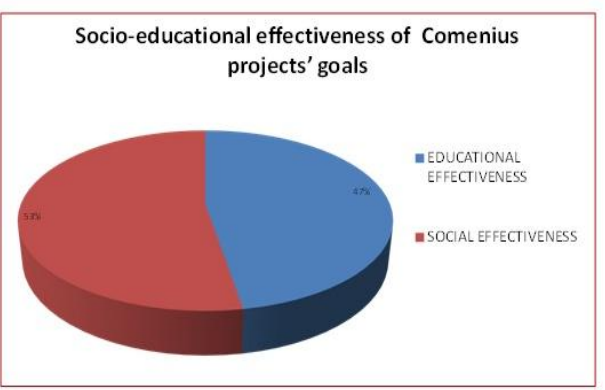


Figure 3. Socio-educational effectiveness of Comenius project's goals-specific feature

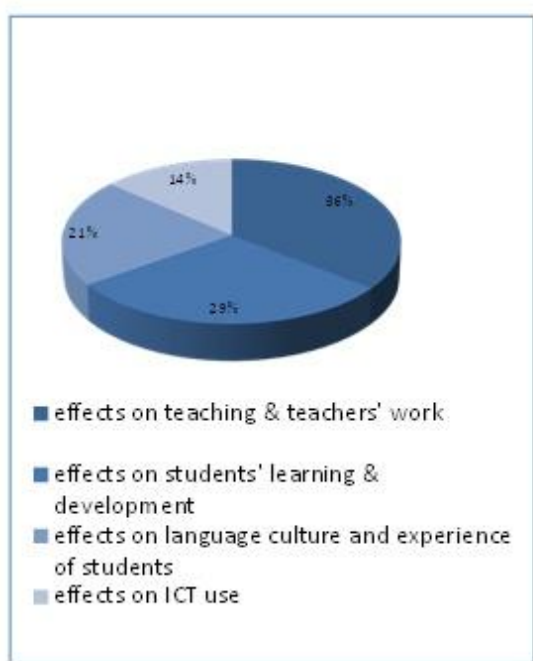

Educational effectiveness as Comenius projects goal

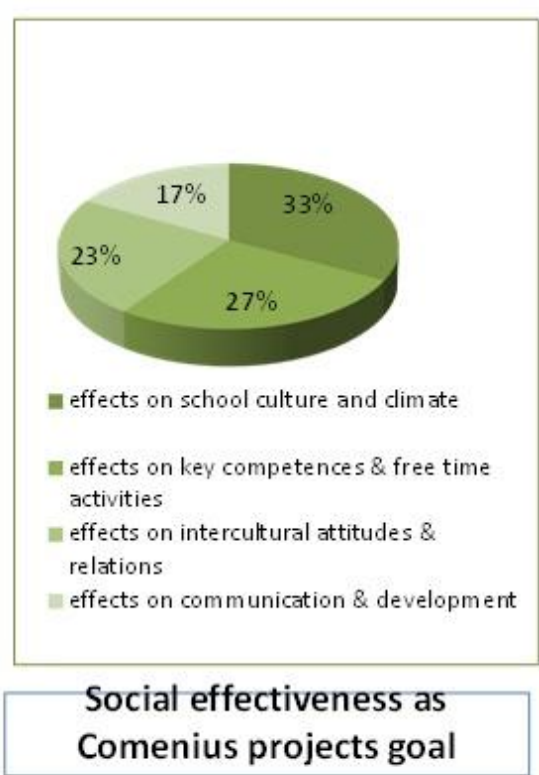

learning activities. The second group (34\%) comprises again of three types of activities - production of project activities, project management and advertisement which relate mainly to aspects of project management and implementation -. The least desired project activities (18\%) are those associated with citizenship education and participation, school development, communication and mobility. All the project activities in this group correlate significantly in their content and meaning with their social effectiveness. (Table 1).

In summary, if theory and practice in the area of project-based learning and teaching has to be supported by a curriculum designed for pre-service teacher education, then it has to integrate teachers ${ }^{\text {ee }}$ competences to use projects as well as tools for academic, social and organizational development. In the context of preservice teacher education this educational need can be satisfied only by integrating theoretical instruction with practical training and internship. 
Table 1. Criteria, items/units and frequencies of the content analysis: project activities

\begin{tabular}{|c|c|c|c|}
\hline Criteria & Units & Frec & \\
\hline \multirow{3}{*}{$\begin{array}{c}\text { Project } \\
\text { activities }\end{array}$} & $\begin{array}{l}\text { - Research activities } \\
\text { - Art activities } \\
\text { - Teaching-learning activities }\end{array}$ & $\begin{array}{l}49 \\
47 \\
42\end{array}$ & $48 \%$ \\
\hline & $\begin{array}{l}\text { - Project management } \\
\text { - Advertis ement } \\
\text { - Working on project products }\end{array}$ & $\begin{array}{l}34 \\
14 \\
51\end{array}$ & $34 \%$ \\
\hline & $\begin{array}{l}\text { - Civic education and participation } \\
\text { - School development } \\
\text { - Communication and mobility }\end{array}$ & $\begin{array}{l}13 \\
10 \\
30\end{array}$ & $18 \%$ \\
\hline
\end{tabular}

\section{Project-based approach as a methodology for pre-service teacher education}

As mentioned above, project-based models and methodologies nowadays play an important role at every educational level and context starting from the pre-school (Reggio Emilia approach) and elementary school practices (Silvia Chard's project approach) and going up to the e/web-based learning projects and project-based in-service training programmes. For the current analysis, two specific educational contexts need consideration, namely those of Secondary and Higher Education.

According to the survey, the practice of project-based education in Bulgarian schools - partners in Comenius 1 projects - combines some basic features of this educational approach successfully (more than $60 \%$ of "yes" choices). Students associate it with working in class on interesting topics $(80 \%)$ while disposing of larger space for independent learning and doing (71\%) and receiving permanent feedback for their work and current achievements $(70 \%)$. In the context of the project work, they find good opportunities to share and present in public their achievements in learning and development $(66 \%)$. According to them a typical feature of this approach to education is also the bigger diversity of traditional and alternative methods, resources and media used in the process $(60 \%)$. Students also associate it with some differences in the curriculum. They think that learning by project helps them to develop useful practical skills such as organizational management and working on authentic tasks and problems $(60 \%)$. Another important specific aspect is the interdisciplinary approach to the educational curriculum combining successfully knowledge and skills from all areas of science and social life (63\%) (Figure 4).

Between $33 \%$ and $65 \%$ of the students positive choices support statements like "projects create opportunities for using research methods in teaching-learning process" (53\%), "school projects involve solving real life problems and completing authentic tasks" (49\%), "they create authentic products" (39\%). Relatively often, students identify as typical for Comenius projects features such as "development of high level intellectual skills" (52\%), "good chances for field work" (43\%), "adults serve as experts" (43\%) and "possibilities to help and be helped during learning" (40\%) (Figure 5). Quantitative analysis shows a substantial difference in students ${ }^{\text {ee }}$ preferences when comparing teaching-learning methods. Statistical data gives reason for defining the project-based school practices as significantly more preferred and valued 
than the practice of traditional approaches and methods (Table 2, $3 \&$ 4).
Parallel analysis demonstrates that only two indicators have closer quantitative

Figure 5. Relatively frequent and positively identified features of project-based learning and teaching (by 30 to $60 \%$ of the students)
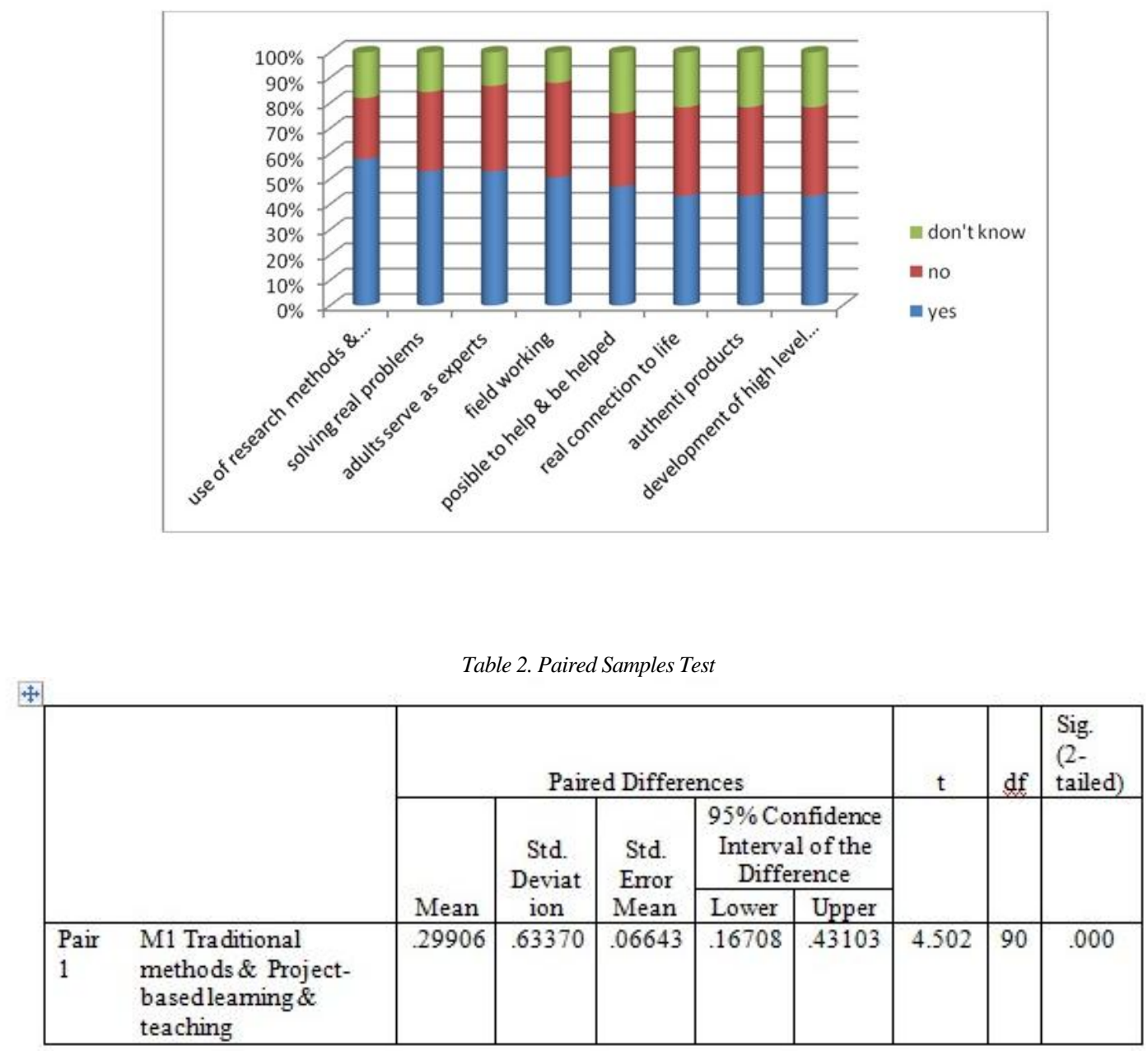

Table 3. Paired Samples Statistics

\begin{tabular}{|cc|c|c|c|c|}
\hline & & Mean & $\mathrm{N}$ & Std. Deviation & Std. Error Mean \\
\hline Pair1 & M1 Traditionalmethods & 2.7883 & 91 & .60587 & .06351 \\
$\begin{array}{c}\text { M1b Project-based } \\
\text { leaming \& teaching }\end{array}$ & 2.4893 & 91 & .34680 & .03635 \\
\hline
\end{tabular}

Table 4. Paired Samples Correlations

\begin{tabular}{|ll|c|c|c|}
\hline & & $\mathrm{N}$ & Correlation & Sig. \\
\hline Pair 1 & $\begin{array}{l}\text { M1 Traditionalmethods \& Project- } \\
\text { basedleaming \& teaching }\end{array}$ & 91 & .204 & .052 \\
\hline
\end{tabular}


values for both traditional and projectbased learning and teaching, namely "methods and forms of evaluation" (R6) and "teachers" role"(R7) (Table 5).

This fact leads to the conclusion that students find significant differences between traditional models of instruction and project-based learning and teaching in most of the compared aspects. The greatest differences reflect the specific aspects of both approaches in areas such as "goals and expected effects" (R1), "development" (R2), "motivation, interest and comfort in education" (R3), "process"(R4) and "teaching methodology" (R5).
For both of the compared approaches in education, the closest to the "yes" are the mean values of two indicators namely "development" (R2) and "process" (R4).

To sum up, students recognise that project-based education makes a positive difference in their school and learning experience, especially when compared with traditional forms and methods of teaching and learning. Similar experience has been registered by other Bulgarian authors in the area of the higher education and especially in the initial teacher education [7].

Table 5. Paired indicators values

\begin{tabular}{|l|c|c|l|}
\hline \multicolumn{1}{|c|}{ Paired indicators } & Mean TM* & Mean PBLT** & \multicolumn{1}{c|}{ Paired indicators } \\
\hline R1 Goals \& expected effects & 2.6538 & 2.1575 & Rlb Goals \& expected effects \\
\hline R2 Development & 2.4963 & 2.0934 & R2b Development \\
\hline $\begin{array}{l}\text { R3 Motivation, interest, } \\
\text { comfort }\end{array}$ & 3.3938 & 3.0678 & $\begin{array}{l}\text { R3b Motivation, interest, } \\
\text { comfort }\end{array}$ \\
\hline R4 Process & 2.4817 & 2.1026 & R4b Proces \\
\hline R5 Teaching methodology & 2.7363 & 2.2143 & R5b Teaching methodology \\
\hline R6 Evaluation & 3.0769 & 2.9121 & R6b Evaluation \\
\hline R7 Teacher's role & 2.6795 & 2.8773 & R7b Teacher's role \\
\hline \multicolumn{2}{|r|}{ *TM - traditional methods } &
\end{tabular}

4. Challenges to implementing project-based methodology in preservice teacher education

There are no universal solutions in the educational practice that would work in every environment and would satisfy every sort of educational need. Based on lessons learned from existing experience some basic weaknesses, problem areas and warnings can be formulated.

\subsection{Lack of clear definition of project typology and functions in educational process}

During their university studies, teachers often have to work on several projects. Some of them are designed to support acquisition of skills for independent study and critical thinking. Others help them practice their practical skills and competences. At times, however, lecturers and/or tutors may fail to explain in detail the development or results pursued by completing the assigned type of learning project.

\subsection{Insufficient preliminary preparation} for using projects as learning methods and tools

To complete successfully their project assignments, student teachers need some preliminary knowledge and skills. Even if they have worked on projects in secondary school, university education challenges them seriously. Given that project-based thinking, studying and/or working already belong to the so called 
key competences, it definitely makes sense to train university students to acquire the relevant skills and qualifications. Different approaches and methodologies for this may be used. Sometimes, it can be done together with the main module/subject curriculum. In other circumstances, degree programmes include specific/separate training module.

\subsection{Wrongly defined driving question / problem}

Every learning or practical project is based on a specific driving question or problem. To choose and introduce the right one is often the most important decision for the final success and the quality of achievement. In this respect, criteria such as correspondence to authentic needs, goals and context, accessibility, clear articulation of the problem 's background and functions, real potential to be solved by students during their guided learning can help them with formulating the driving question.

\subsection{Poor time and process management}

Time and process management are typical challenges for every kind of human activity that is especially organised. Difficulties can be generated by poor planning and incomplete preliminary organization of the main project activities. Poor time and process management can also be the consequence of choosing a wrong driving question for the project, as well as of overestimating studentse ${ }^{\text {ee }}$ potential and competence for fulfilling the assignment.

\subsection{Inadequate evaluation methods and procedures}

According to the research, the area of evaluation is in fact the only one where students don't see positive development or change comparing the traditional and project-based context (both mean values are close to the "no" choices marked with 3 and 4 in the implemented scale). In general, the selection of appropriate evaluation methods is one of the weakest elements in project-based education models. This is why everyone who intends to use its potential should be aware of possible risks and errors.

\section{Conclusion}

There are several reasons for considering project-based learning and teaching as a successful approach for quality preservice teacher education worldwide. Its broad implementation in the area of both formal and informal education and training provides strong arguments for positive evaluations and high expectations. However, like every other method or technique used for educational needs, project-based approaches and models need to be seriously analysed and well-planned before being introduced into the practice.

\section{References}

[1] Knoll, M. (1997). The project method: Its vocational education origin and international development. Journal of Industrial Teacher Education, 34(3), pp. 59-80. [Full Text] [Back to text]

[2] Knoll, M. (2011). I Had Made a Mistake. William H. Kilpatrick and the Project Method. Consultado en: http://www.tcrecord.org/Content. asp?ContentId=16242. [ [Abstract] [Back to text] 
[3] Kilpatrick, W. H. (1918). The project method. Teachers College Record,19, 319-335. [Back to text]

[4] Branom, M.E. (1919). The Project Method in Education, Boston, A.G. Badger: Roberts University of Toronto. [Full text] [Back to text]

[5] Henry, J. (1994). Teaching through projects, Kogan Page, p.13. [Abstract] [Back to text]
[6] Stimson, R. W. (1915). The Massachusetts Home Project Plan of Vocational Agricultural Education. The School Review, 23 (7), 474-478. [Full text] [Back to text]

[7] Пейчева, Р., Дизайн на университетския курс, С., (2002). [Back to text] 